\title{
Deviant politics and Jewish love: Alfonso VIII and the Jewess of Toledo*
}

\section{DAVID NIRENBERG}

History Department, The John Hopkins University, 3400 North Charles Street, Baltimore, MD 21218, USA

E-mail: nirenberg@jhu.edu

\begin{abstract}
The story of King Alfonso VIII of Castile's affair with a Jewess of Toledo is perhaps the most famous medieval account of love between a Christian and a Jew. This article begins with the story's first appearance toward the end of the thirteenth century and traces its expansion across several hundred years, in order to describe the roles played by figures of Judaism (and of women) in enacting and representing conflict within Christian politics. Once embedded in Castilian political theology, the Jewess reveals a good deal about how and why charges of Jew-love and Judaizing were deployed in late medieval conflicts over new forms of monarchical power, centralizing government, and administration. The article concludes with a focus on the Jewess' role in both legitimating and criticizing a particularly important practice: the increasing royal delegation of administrative power to one favored minister (privado). By placing the Jewess at the center of debate over this practice, the article demonstrates how she simultaneously contributed to and reflected a transformation of the possibilities for Christian politics in Castile and for Jewish life in Sefarad.
\end{abstract}

"Love" of Jews was a frequent accusation against Christian princes in medieval Christendom. In the words of Ramon Martí, "What do you think that the devil can accomplish through the Jews..., so loved by our princes on account of the services they provide and the flatteries they spew forth?" Less often, this accusation took the form of carnal love, fleshy and physical. Guibert of Nogent, for example, excoriated the Count of Soissons for his affair with a Jewess. Count Thibault of Blois is said to have had relationship with a Jewess called Pucellina, which ended with his burning a number of her co-religionists alive on charges of ritual murder in 1171. According to Polish legend, King Casimir the Great (1310-1370) so loved the Jewess "Estherke" (Esther) that in 1334 he granted the Jews his "Golden Bull" of privileges in her honor, and after her death kept her eyes and heart in a box by his

* The present article is a much revised and expanded version of "Alfonso VIII and the Jewess of Toledo: A Political Affair," in Essays in Honor of Denah Lida, ed. M. Berg and L.A. Gyurko (Boston, 2005): pp. 27-43. Like its precursor, it is dedicated with love to my great aunt. 
bed. ${ }^{1}$ But of all of these love stories, perhaps the most interesting, as well as the most long-lived, is told by a king himself, King Sancho IV of Castile (r. 1284-95).

Sancho was a dutiful parent, if not a faithful son. At some point not long after bringing the civil war against his father Alfonso $\mathrm{X}$ to its successful conclusion, he (or his ghostwriters) began to draft a manual of proper conduct for his own heir Fernando. Among the many moral and political lessons that Sancho hoped to impart to his child through the Castigos was a strong sense of the value God attributes to royal chastity. The lesson was often repeated, but in chapter 21 it took on a curious shape:

...My son... consider the punishment that happened to king don Alfonso of Castile, the victor in the battle of [Las Navas de Tolosa, 1212]. For the seven year that he lived the bad life with a Jewess of Toledo God, punished and beat him in the battle of Alarcos (1195), in which he was defeated and fled, and it went badly for him and for all the subjects of his realms... God also killed all his sons, so that his grandson Ferdinand, son of his daughter, inherited the kingdom. He repented of such a bad sin as this one that he had committed, and later built the monastery of Las Huelgas in Burgos... as penance, and God gave him afterward victory against the Muslims in battle. But whatever good fortune he had, it would have been much better if he had not been first defeated at the Battle of Alarcos, in which bad fortune he fell because of his sin. ${ }^{2}$

Here, anonymous and cramped into a handful of humble words ("he lived a bad life with a Jewess of Toledo"), we first encounter the most famous Jewish woman of Iberian letters. Her story would be written and rewritten for the benefit of audiences, early modern and modern, moved by mesaliances: Lope de Vega's Las paces de los reyes y judía de Toledo, Franz Grillparzer's Die Jüdin von Toledo, and Lion Feuchtwanger's Spanische Ballade/Die Jüdin von Toledo, these are only a few of the later works of fiction that animate our skeletal Jewess in order to explore the furthest reaches of star-crossed love. ${ }^{3}$

Historians, too, have been attracted by the story. Most insistently they have asked of the Jewess, is her story true? Modern scholars have most often approached this question by scrutinizing the troubling century of silence that separates the Jewess' alleged existence (sometime prior to 1195) in the early part of Alfonso VIII's reign (1158-1214) from her first appearance in the histories (ca. 1292). ${ }^{4}$ Why 
did her story only begin to be told in the late thirteenth century? This silence apparently concerned the early chroniclers as well. Already in the Crónica de Castilla (whose surviving Gallician-Portuguese version dates to 1295-1312) the story is attributed to the early thirteenthcentury historian Rodrigo Jiménez de Rada (c. 1170-1247). Later chroniclers deleted the attribution, perhaps aware that this august Archbishop of Toledo never mentioned the Jewess in any of his known writings. ${ }^{5}$ Rodrigo's De rebus Hispaniae was one of the pillars for the great historical edifice built by Sancho's father Alfonso X, whose pinnacle was the Primera Crónica General. That chronicle too ignored the Jewess, even though it happily embellished other accounts of interfaith affection (such as that of Alfonso VI's marriage with the Muslim princess Zaida) and its chapter on Alfonso VIII was probably redacted shortly after 1289 (that is, well after Alfonso X's death and at much the same time as the Castigos). ${ }^{6}$

Scholars also find reason for worry in the story's rapid expansion: in the few years that intervene between the composition of the Castigos and the Crónica de Castilla the tale had spread across three chapters. Chapter 502 of the Crónica blames Alfonso VIII's defeat at Alarcos on the factionalism and tepid loyalty of his vassals, but attributes that disloyalty to God's punishment of the king's youthful sin. Chapter 503 describes the expiation of that sin through the founding of Santa Maria de las Huelgas at Burgos. And Chapter 491 records the sin itself:

After the king Alfonso was married, as you've already heard, he departed to Toledo with his wife. And while there he saw a very beautiful Jewess, and he became so attached to her that he left the queen his wife and shut himself up with the Jewess for a very long time, in such wise that he could not part from her for any reason, and occupied himself with nothing else. And as the Archbishop Rodrigo tells it, he was shut up with her for seven months, so that he paid no heed to himself, nor to his kingdom, nor to anything else. And they say that this great love that he had for the Jewess was caused by spells and love magic that she knew how to make. But the counts and barons and rich men, seeing that the kingdom was in such danger because of this, agreed together on how they would resolve this terrible and unconscionable deed. And the agreement was that they would kill her. And with this intention they entered to where the king was, pretending that they wished to speak to him. And after all had gone in before the king, while some spoke to him the others 
entered to where the Jewess was and... they cut her throat and did the same to the others who were with her.... And when the king learned this he was so unhappy that he did not know what to do, for he loved her so much that he wanted to die with her. And then some of his vassals took him and transported him to a place called Illescas.... And as he lay one night preoccupied by the affair of this damned Jewess there appeared an angel who said: how now, Alfonso, are you dwelling on the evil you have done, from which God received great disservice? You do ill, for know that He will charge you dearly for it, you and your kingdom, for it consented to your sin. ...And then the angel disappeared, filling the room with a great odor, clear and good. ${ }^{7}$

Here we have at last the drama that would attract the likes of Lope de Vega. The Jewess remains anonymous and un-described, but the power of her beauty is amply reflected in the king's lovesickness: his distraction during her life, his melancholy after her death. We even catch a glimpse of her in a richly furnished chamber, surrounded by unnamed companions who share her fate. The cast of characters, too, has grown, first by a band of nobles so concerned about the state of the realm that they agree to deceive the king and murder the Jewess in his court; and then by a sweet-smelling angel who visits and upbraids the disconsolate monarch.

Historians are generally suspicious of expansion, and this case is no exception. Diego de Colmenares in the seventeenth century, the Marques de Mondéjar and the Padre Flórez in the eighteenth, in the nineteenth Fidel Fita, all decried the affair as implausible legend. Others defend love but protest the details. ${ }^{8}$ Strangely enough it is not the angel but the barons who attract scholarly ire. In words penned by Marcelino Menéndez y Pelayo, “...what is most unlikely and most insulting in the story is not that the king should be taken by a very beautiful Jewess, but that the great men of Castile should plot together to assassinate a miserable woman." The Jewess' most recent student concurs: historical material underpins Sancho's account. But the betrayal of the king and the murder of his lover, these must be the embroidery of overheated imaginations. ${ }^{9}$

Of course a great deal has changed over the centuries of critical engagement with the Jewess. Over the past generation of literary studies alone, focus has shifted from questions of truth and transmission to questions of representation. "Even if the tales are not real, they are true in the sense that they mirror and heighten situations, perceptions, and tensions inherent in a society," as Edna Eizenberg put it in her 
study of the Jewess some twenty years ago. The Jewess' story now serves to illustrate, not the ideal of chastity, but the compulsion of the powerful to sexually objectify the weak. Like so many other peoples ravished in histories, she becomes a "tool for asserting in-group values and dominance, all the while affirming male supremacy." For Eizenberg, as for many of the scholars working on literary representations of gender and sexuality in the Iberian Middle Ages, the challenge is to demonstrate how, in Foucault's famous words, "power... dictates its law to sex." 10

Such readings are productive and liberating, in that they move from "event" to "discourse" and "representation." They are also ethically attractive, in that they seem to turn our attention from the powerful to the oppressed. But pre-modern power did not speak with one voice, and pre-modern sex took poor dictation. Because claims about love were the terms in which conflict, both political and hermeneutic, were expressed and negotiated in the Christian Middle Ages, the relationship between politics and sex was one of co-dependence, not of tyranny. Our story is a product of this co-dependence. How to discriminate between political and textual practices that are the products of legitimate love between sovereigns and subjects, and those which are not? This is the basic constitutional question posed (though certainly not answered) by the Jewess of Toledo. Her romance, it turns out, can teach us a great deal, not only about conflicts over new forms of governance (such as royal favorites, ministers, and bureaucracies) in late medieval political orders, but also about the roles played by figures of Judaism (and of women) in enacting and representing these conflicts within Christian political theology.

"You shall be free to set a king over yourselves, one chosen by the Lord your God," grants Deuteronomy 17, but “...he shall not have many wives, lest his heart go astray." (vv. 15-17) Within the context of the ancient Near Eastern polities of Egypt or Mesopotamia, where uxorial expansion was a basic instrument of political incorporation, this restriction of the Israelite sovereign's sexual alliances was remarkable, and came to form a distinctive theme of Israelite manuals on kingship. Thus the Book of Proverbs (which, like Sancho's "Punishments," takes the form of admonitions addressed to his son) represents right rule as resistance to the seduction of "forbidden women." 11 This representation, which permeates the entire book, sometimes takes dramatic form:

My son, heed my words; and store up my commandments.... From the window of my house, through my lattice, I looked out and saw... a woman. She lurks at every corner. She lays 
hold of him and kisses him.... She sways him with her eloquence, turns him aside with her smooth talk. Thoughtlessly he follows, her, like an ox going to slaughter... Now my sons, listen to me, pay attention to my words; Let your mind not wander down her ways.... Her house is a highway... leading down to Deaths inner chambers. ${ }^{12}$

We cannot explore the relationships between these stagings of sovereign seductions in the Hebrew Bible and medieval Christian ones. Suffice it to say that the dangers posed to Christian monarchs by deviant love have a pedigree rooted in Hebrew Scripture, and that the ways in which biblical kingship "manuals" like Proverbs imagined those dangers influenced the literary imagination of medieval ones.

It is therefore unsurprising that Alfonso VIII and his Jewess are not alone in the "Punishments." They appear in the midst of three chapters (19-21) devoted to describing correct political order in terms of the proper sexual relationship to the sacred. Chapter 19, entitled "How man should not grieve God [by having sex] with women with whom he ought not or where he ought not"["Commo non deue omne fazer pesar a Dios con mugeres con que non deue e o non deue"] introduces the general topic. God takes special offense, the chapter begins by explaining, at sins committed with women in religious orders, married women, virgins, Jews, and Muslims. ${ }^{13}$

In the case of religious women (who form the specific subject of Chapter 19), this is because a nun is "married to God." "[H]e who wants to take the wife of God, his lord, commits great treason." Just as it would obviously constitute "great madness" for a poor man to fight with his rich lord, so it is folly to offend God by stealing his brides. The point is made through a political proverb: "Whether in jest or in earnest, never take liberties with your lord." It is brought home (as are all moral claims in the Castigos) by a vivid example. A nun is sneaking out of her monastery to meet a would-be-lover. Passing the main altar she genuflects and whispers a furtive Ave Maria. The Virgin's statue begins to scream, the crucified Jesus jumps from his crucifix to give chase. Just as the nun reaches the gate he clubs her with his arm, driving through her jawbones the nail that had fixed his hand to the cross. Then he returns to his crucifix, leaving the nun impaled on the floor, the nail sticking out of her chin.

The denouement is predictable: the nun is revived and repentant, the knight becomes a monk, the crucifix displays henceforth a crooked arm. The moral, too, is near: if mute images, made of wood by the 
hands of man, take umbrage at such sexual treason against God, how much greater must be the anger of God and the Virgin herself? Because in the Castigos divine anger so often has military consequences, the chapter concludes with an account (and in Manuscript $\mathrm{C}$ an illustration) of a contemporary battle in which Pedro Coronel defeats Juan Corualan thanks to the intervention of a (now spectral?) nun with whom the latter had once sinned. ${ }^{14}$

Sancho's Muslim and Jewish women moved in the same moral, political, and narrative landscape as these erotic nuns and their married (Chap. 20) and virgin (Chap. 21) Christian sisters. Of course sex with non-Christians offends God not because, as is the case with nuns, their love is pledged to him, but because they are His enemies. In the case of Jews, who rejected Jesus' kingship and torment him in the flesh, Sancho emphasized the disparity between religious enmity and physical love through a graphic image: "Moreover, you should not in intimacy bring your face close to that of the Jewess, for she is of the lineage of those who spat in the face of Jesus Christ, your Lord."15 This imagination of disloyalty to God in terms of sexual intercourse with unbelieving women is part of an ancient sensibility: Jewish and Christian scripture often made claims about the exclusive nature of religious loyalties through stories of inappropriate love. ${ }^{16}$ Sancho chose only one scriptural proof-text, the popular Old Testament example of King Salomon, "que fue tan sabio omne, mugeres de otra creençia le tiraron de la su ley e le fizieron que dexase el al dios de Dauid..." (p. 133), but he could have chosen many others. Seen from this discursive distance, the rejection of the Jewess in Sancho's story becomes a performance of religious loyalty, an assertion of "in-group values and dominance," and an account of the boundaries between competing monotheisms. Hence it is at this point in the Castigos, in a chapter ostensibly devoted to constraining princely libidos, that the reader is provided an account of the messianic errors of the Jews as well as a polemical history of Muhammad and the origins of Islam.

Though Sancho presents his tale as an account of the transcendent loyalties owned by earthly monarch to heavenly king, one of the most powerful features of this sexual model of religious order and loyalty was its ability to be mapped onto a more explicitly political order. As Sancho himself explains in the case of Alfonso VIII, God punishes the transgressions of the ruler in the bodies of the ruled. The piety of the ruler is therefore reflected in the political order of his kingdom. This ancient theme, central to much medieval Christian political theology, emerges from the very beginning of the work: Adam rebelled against 
God, hence his own flesh and all of creation rebelled against Adam: "por tal commo fue rebelde a Dios, por tal se le rebello su carne propria, e todas las bestias le fueron rebeldes." The sexual foundations of these political disorders appear just as early. Adam's error began by wanting to please Eve. In yielding sovereignty to his wife he sowed the seeds of the first, and paradigmatic, rebellion: "And as punishment for this our Lord God has ordained that whenever man gives woman lordship over himself, she will always be contrary to him."17

This gendered political history of Eden serves as a template for the political history of Spain. Thus Sancho concludes the prologue, "I wrote this book in the year that with the help of God I won Tarifa from the Moors to whom she belonged, and who had held her in their power for more than six hundred years since the King Rodrigo lost her, who was the last king of the Goths, because of the evil and the abominable treason of the bad count Don Julian, and I gave her to the faith of Jesus Christ, and there are in [the book] fifty chapters." The political and moral claim is clear. Spain had been lost because of treason and rebellion awakened by Rodrigo's sexual sin, and could only be regained by monarchs both pious and chaste. ${ }^{18}$ Sancho was not an obvious candidate. He had, after all, not only usurped the throne, but also abandoned his promised bride in favor of "marriage" with María de Molina, a woman he first met when she acted as Godmother at the baptism of his illegitimate daughter. (Their union was never sanctioned during his lifetime, nor their children legitimated, despite efforts that included the forging of papal bulls.) ${ }^{19}$ According to the logic of the text, however, Sancho's victory over the Muslims at Tarifa, like his authorship of the Castigos, proved him to be such a sovereign.

Alfonso's Jewess operates within this moral economy and this political project, but she does a specific type of work that other textual women, Muslim or Christian, could not do. Compare, for example, the often told story of Alfonso VI's relationship with the Muslim princess Zaida. That love, which resulted in Zaida's conversion and concubinage with the king, served not to reproach Alfonso, but to praise him. Insofar as royal intercourse with Muslim women implied (at least in the Castilian literary tradition) a domination of Islam, it expressed positive values of conquering Christian virility. The Primera Crónica General even uses the story of Zaida as the frame within which to narrate the arrival from North Africa of Almoravid armies toward the end of Alfonso's reign, representing his encounter with these armies as victorious vengeance for their murder of Zaida's father al-Mu'tamid, the emir of Seville. The fact that the Almoravids halted Christian 
expansion for a generation did not prevent the use of Alfonso VI's relationship with Zaida to represent the culmination, rather than the reversal, of his conquests. ${ }^{20}$

As for kings and Christian women, there were plenty of stories in which defeat was attributed to inappropriate sex. Jaume I of CataloniaAragon, for example, explained his father Pere's support for the Languedocian nobility during the Albigensian crusade as a result of his desire for their wives and daughters, and his death in 1213 on the battlefield of Muret as the consequence of exhaustion from too much intercourse with a courtesan the night before. ${ }^{21}$ But at the same time that they criticized royal sexual energy, contemporaries also understood it as a natural manifestation of power, and assigned unmarried sexual partners of the king an honorable and legally defined space. ${ }^{22}$ Alfonso's relationship with the Jewess of Toledo evoked no such understanding. Its consequences were not only defeat, but even more pointedly, rebellion.

The word is sharp, but deliberate. Sancho himself had stressed defeat and disorder, not rebellion, in his telling of the tale. Notwithstanding his precautions, the political and moral implications of Alfonso and his Jewess could not be easily denied, and within a few years the Crónica de Castilla had articulated what the Castigos left unspoken: Alfonso's errant love must have been punished by baronial revolt. Not only did the king's vassals fail in their duty to fight for him against the Muslims at the battle of Alarcos, they also violated his court, murdered his mistress, and dragged him to Ilescas. In other words, the king's Jewish affair fomented treason, and that treason brought about the kingdom's defeat at the hands of Islam. In the Crónica de Castilla and the Crónica de 1344 the angel articulated the operative constitutional logic. The kingdom was punished, not merely because the king had sinned, but because the kingdom "had consented" to his sin: "Et el angel le dixo sed çierto que tan gran saña a Dios de ti por este pecado que telo demandara y al tu rreyno porque lo consintio." 23 Kingdoms that indulge the deviant loves of their kings will suffer. The barons' only error was in not having rebelled earlier.

This linkage of "Jew love" and rebellion was not incidental: rebellion was peculiarly "Jewish" territory in late thirteenth century Castile. This "Jewishness" emerges strongly in the accusations made against Sancho's own father Alfonso X by those who resisted his rule. The aristocratic uprisings of 1270-1275, for example, complained of royal taxes (servicios), and of the use of Jewish administrators to collect them. Rebellious grandees claimed the revenues farmed on behalf of the 
king by his Jews and even took some of these Jews hostage. With the suppression of the rebellion in 1275, however, Alfonso entered once more into arrangements with his Jewish administrators, granting extensive control of his financial administration to Isaac ibn Zadok (aka Çag de la Maleha) in 1276. By 1279, when a council of bishops met to complain about Alfonso's rule, “Alfonso X's accusers represented him as a barely Christian tyrant manipulated by Jewish counselors, intent upon subjecting churchmen to an intolerable yoke of persecution and servitude." It is in this context of these criticisms, and of increasing tension between the King and Prince Sancho, that Alfonso ordered the imprisonment of Jewish tax farmers, and the hanging of Isaac/Çag. Sancho himself, unwilling to see the throne pass to the young children of his deceased elder brother, first flirted with, and then espoused revolt. He married into the aristocratic party (quite literally: María de Molina came from a powerful clan of magnates) and made himself the champion of their complaints, attacking the Jews and their royal protector. ${ }^{24}$

We could therefore interpret Sancho's use of the story of Alfonso and the Jewess as an oblique legitimation of his own rebellion, one that condenses the political anti-Judaism used against his father, retells it as a gentle tale of sexual rather than fiscal love, and projects it onto safely heroic ancestors. Yet the story describes Sancho's reign just as well as his father's. Consider Sancho's infamous relationship with Lope Díaz de Haro. Lope was head of a lineage that had sided with Sancho in his war against Alfonso X and those lineages (most notably that of the Laras) that supported him. ${ }^{25}$ Sancho rewarded Lope with the title of Count, with his own sister in marriage, and in June of 1287 with the role of "Privado," or "governing favorite," granting him complete authority over chancery, treasury, and government. Lope in turn granted the Jew Abraham de Barchillon centralized responsibility for much of the crown's income, and Abraham immediately began recuperating for the Crown revenues alienated during the civil war to nobility and clergy. Resistance was just as immediate. Convinced by his magnates (and by the queen) to reverse course, the king rescinded Abraham's actions in the Cortes of July and August 1288. A ban was declared on the use of Jewish tax collectors, and the magnates rewarded with a distribution of royal revenues. Don Lope himself, however, suffered a more striking reversal, one that burned itself deeply into historical memory. Like Alfonso's Jewess, he was stabbed to death in the king's court at Alfaro on 8 June, $1288 .{ }^{26}$

Of course the Castigos attempted to tell the story of Alfonso's Jewess in such a way as to strengthen Sancho's claims to sovereignty, 
while at the same time repressing the potential for rebellious violence which accusations of royal philo-Semitism authorized in his father's reign and his own. In his telling, Alfonso VIII's error was characterized as infatuation and love-sickness, not corrupt materialism or tyranny; God, not the barons, punished the wayward king; and Alfonso (like Sancho, are we meant to conclude?) went on to great victories despite early sin. But despite Sancho's narrative efforts, it is clear that the sharp edge of the Jewess cut as deeply into his own reign as it did into his father's, and that other authors (like those of the Chronicle of Castile or of 1344) were quite willing to turn her blade against their king.

In a handful of years, we have seen the humble Jewish concubine of the Castigos transformed from a representation of the sovereign's special relationship with God, into an exemplary tale of monstrous monarchical affection justifying revolt. One way to explain this growth is to understand her figure as a precocious part of a political discourse that criticizes certain aspects of royal governance, and particularly financial administration, as "Jew loving." This representation drew its power from (at least) three interrelated phenomena. The first was the increasing weight of the fiscal and administrative practices that supported the expansion of royal power beginning with the reign of Alfonso X. The proportionality of the role played by Jewish administrators in this expansion is a matter of irresolvable (given the nature of the evidence) debate: to my mind it has been much exaggerated. ${ }^{27}$ The negative association of royal fiscal power with Judaism seems to me to be as much the product of the tools available to Christian theology for the representation of materialism and its dangers as it was of the functions real Jews carried out in medieval taxation and administration. As Sancho put it in the Castigos, the greatest enemies of good Christian kingship were the devil, the world, and the flesh: three things Christians had long associated with and represented through Jews. ${ }^{28}$ But regardless of whether the "Jewishness" of fiscality was the product of real Jews in royal service, of Christian political theology, or of some combination thereof, what is clear is that complaints about Jewish influence and charges of royal philo-Semitism became a preferred weapon in the increasingly sharp debates over taxation and administration that marked the late thirteenth, fourteenth, and fifteenth centuries.

We have already seen this charge deployed in the reigns of Alfonso and Sancho. The idiom became routine in those that followed, with the accent sometimes thickening in open rebellion. The aristocratic factions 
that deposed and murdered King Pedro I "the Cruel" (1350-1369) in the mid-fourteenth century justified their actions by portraying him as a favorer of Jews, and even claimed that he was a cuckoo, the son of a Jewess adopted by the queen mother to conceal her inability to provide an heir. Much as Sancho had done a century and a half earlier, Prince Enrique (IV) rebelled against his father Juan II and his "Jew-loving" minister Alvaro de Luna, charging that they empowered Jews over Christians. He himself would later be ritually deposed in the "farsa de Avila," accused of sodomy, favoring Jews, and living like a Muslim. Even the "Catholic monarchs" Fernando and Isabel, conquerors of Granada, founders of the Inquisition, expellers of the Jews, were said by some of their subjects to be descended from Jews and to benefit them in their policies. ${ }^{29}$

The utility of this linkage between "Judaism" and fiscal power grew with the increasing weight of taxation and administration in an era of what has sometimes been called "state formation." It is this expanding utility that accounts, in part, for the sudden appearance of our "Jewess" in the late thirteenth century, and for her rapid discursive transformation into a legitimation of revolt. Her figure was animated, however, not only by the increasing weight of government, but also by conflict between monarchs and magnates over control of that government and its profits. Through hereditary office and countless other devices, the great nobles sought to retain as much control over royal administration as possible. Kings, on the other hand, beginning especially with the reign of Alfonso X "the Wise," developed strategies to maintain and increase the autonomy of that administration from the nobility. Alfonso's Jewish concubine combines in one figure both a defense and a critique of some of these practices, and is therefore an interesting character in the history of medieval governance.

One of these practices, already touched upon, was the use of Jews as administrators. A second is the expanding administrative importance of queens and concubines in the same period as the story of our Jewess was growing. Sancho himself had solidified his leadership of the aristocratic factions arrayed against his father through his union with María de Molina. Her maneuvers to maintain her position in spite of the legal flimsiness of her "marriage" contributed to the fall of Lope de Haro and to that of the privado who had preceded him, the abbot Gomez García. ${ }^{30}$ Later she served as regent during the minority of her son Fernando IV (from 1295-1301), defending his rights to the throne against a series of well-armed rivals alleging the illegitimate nature of Sancho's own accession. After the deaths of Ferdinand and his wife (in 
1312), she again exercised guardianship of her grandson Alfonso XI (1311-1350), while a swirl of competing aristocratic factions contested the regency and divided among themselves the spoils of government.

Queens as regents were not news. More innovative was the politics of concubinage developed by Alfonso XI (and later his son Pedro I) during the decades that the story of our Jewess was growing. Barraganas had long been part of the sexual lives of kings: nearly every monarch of Castile from Alfonso X until Isabel made provision in his testament for the maintenance of his concubines and their children. ${ }^{31}$ Alfonso XI and Pedro, however, confronted a particular dilemma: their emancipation as rulers required that they dislodge the rival factions that had gained control of the resources of government during their minorities. Marriage was here a tool of limited utility. If they wished to increase their autonomy from the great nobility, kings could not, as the rebellious Sancho IV had done, marry into it. Not surprisingly, both were betrothed to foreign princesses: Alfonso XI to María of Portugal, Pedro I to Blanche of France. But such marriages did not bring with them what kings most needed: a loyal faction of one's own. From 1329 until his death, the young Alfonso XI depended, not just on the advice of his mistress Leonor de Guzmán, but also on the service of members of her family, whom he placed in positions of authority and power. Like his father, Pedro was 18 years old when he met a young woman from the lesser nobility named María de Padilla. Like his father (though less successfully) he ennobled and enriched her relatives, assigning to them the most sensitive posts of his administration. ${ }^{32}$

The moral valence accorded to this politics of concubinage in literary representations depended, of course, on its outcome. Chroniclers looking back upon the reign of Alfonso XI, for example, explained Leonor de Guzmán's influence over him in the traditional terms of beauty and virtue: her children, after all, were eventually victorious in founding a new dynasty. The posterity of Pedro's affair was quite different, left as it was to the tender mercy of the triumphant Trastamaran propagandists. According to them, María de Padilla gained her ascendancy over the king by commissioning a Jewish necromancer to enchant the jeweled belt Queen Blanche had given Pedro on his wedding night, so that it turned into a serpent and frightened him away from the marriage bed. ${ }^{33}$

The critical power of our Jewess owes something to this sexual politics of queens and concubines, but it is even more closely intertwined with the rise of another form of "governing affection," that of the privado, or beloved councilor, who enjoyed the special favor and 
intimacy (privanza) of his lord. In the political vocabulary of our period, love and intimacy were understood as powerful inspiration for and representations of political confidence: hence kings and princes were well advised to depend upon amor and privanza in choosing the administrators of their and the kingdom's affairs. ${ }^{34}$ But as we have already seen, the power of love was dangerously ambivalent: on the one hand the basis of a well-ordered republic oriented toward the divine; on the other seducing the monarch, as Sancho repeatedly warned in the Castigos, into an excess of carnality and materialism.

This danger was encoded in the word privanza from its very earliest usage. We first encounter the word in a text that precedes the appearance of our Jewess by only a generation, and that comes, like hers, from the genre of exemplary admonitions about Judaism's dangers: I mean the famous story of Theophilus, as told by Gonzalo de Berceo in his Milagros de Nuestra Señora. Gonzalo's Theophilus is the chief administrator, chief judge, and chief accountant of his lord the bishop: all that remains for the worthy pontiff are his devotions. In Gonzalo's words, Theophilus had "con el bispo amor e grand privança." 35 It is when, under a succeeding bishop, Theophilus loses that "amor e grand privança" that he turns to a Jew, who brokers the sale of his soul to the devil in exchange for renewed favor. The story of Theophilus' miraculous redemption by the Virgin Mary was a favored one in the Middle Ages, told and re-told (by Alfonso X in his Cantigas de Santa Maria, for example) to make many different points. Ours is a simple one: already here, at the birth of privanza, the Jew stands at the crossroads of administrative love, ready to lead it in the direction of damnation.

Theophilus' administrative love (amor) was the product of a clerical court, normatively celibate and childless. Perhaps for this reason Gonzalo de Berceo threatened privanza with Judaism, but not with sex. ${ }^{36}$ In secular courts where political love was more explicitly carnal, the combination of sex and Judaism was more potent. In the case of royal love for ministers in particular, the union of the two was brokered by scriptural example. I am referring, of course, to the explicit representation of ministerial power as sexual, female, and Jewish in the Book of Esther. ${ }^{37}$

The biblical account of how the Jewish concubine and queen Esther called upon the love of King Xerxes/Ahasueros in order to prevent the destruction of her people was well known to medieval Christian and Jew alike. Jewish communities throughout the Diaspora reenacted the story each year at the festival of Purim: it served them as a political allegory 
and a source of hope. For Christians the story also encoded love and sexual union as metaphors for political alliance, inclusion, and protection, but that encoding was much more ambivalent. At the level of a purely Christian political typology, Esther served as an example of the ideal queen, putting herself in danger for her people. Hence, for example, the exhortation to emulate Esther in queenly coronation ceremonies, or the prominence of the coat of arms of Blanche of Castile (who was, coincidentally, Alfonso VIII's daughter) in the Esther window at the Ste. Chapelle. ${ }^{38}$

From another point of view, however, the story was much less comforting. Like Don Sancho's Castigos, the Scroll of Esther begins with the general principle that political perils arise whenever woman refuses to be ruled by man. Queen Vashti is condemned for disobeying the king's order to dance in front of his court: "The queen's conduct will soon become known to all the women, who will adopt a contemptuous attitude towards their own husbands.... And that will mean contempt and anger all around." [1.16-18] Yet the book concludes with the Jewess Esther and her uncle Mordechai effectively ruling the entire kingdom as Queen and minister of Ahasueros, and indeed expanding its boundaries. In this book, the only one in the Bible that depends explicitly on female authority, God clearly authorizes the deviant power of a woman over a man, and of a Jewish minister over a non-Jewish king: precisely the kind of inversion that Sancho warned against constantly in his Castigos.

The manifold medieval readings of the Book of Esther still await their historian. ${ }^{39}$ What is evident within the Christian and Castilian context that we have been describing, however, is the book's power to underwrite a broad political critique in which Ahasueros is a bad king, too easily swayed by self-interested councilors, erotic desires, and Jewish ministers; while Esther becomes a negative example of wideranging political power obtained not through lineage but through deviant royal love: in short, of privanza. ${ }^{40}$ Such a reading of Esther could be used to Judaize and feminize the power of kings and their confidants, whether concubines or Counts, in order that this power might be resisted as un-Christian and immoral. Precisely such a Judaization and feminization became a preferred weapon against monarchs and their ministers in the tumultuous history of Castilian politics. But before the story of Esther could be put to the hard work, not just of criticizing monarchy, but of rebelling against "Jew-loving kings," it needed first to be freed from its plain, "philo-Semitic" and "philo-ministerial" meaning. The story of "How the King Alfonso 
remained secluded with a Jewess" achieved this liberation. It restaged the drama of Esther as one in which not the Jewish but the Christian nation was in danger, and then exorcised that danger by reversing the biblical ending: the aristocrats triumph, the concubine dies. ${ }^{41}$

This conclusion begs to be understood as merely a reaffirmation of right rule, masculine and Christian, but it is much more than that. The story of Alfonso and his Jewess proved useful precisely because it represented political conflict in terms of consensus, translating the outcome of sharp struggle between sovereign and subject into gendered and religious terms seemingly sanctioned by nature and divinity. These terms, however, masked their origins in crisis and rebellion, both political and exegetical. The story of Alfonso and his Jewess challenged both monarchical authority and scriptural narrative. That challenge left its marks, not only in the fractured strata of the chronicle tradition, but also in the dramatis personae of the story itself. It is never easy to fly directly in the face of scripture or of sovereigns: hence the angel, who reveals, so to speak, divine approval of assassination and revolt. Angel and Jewess alike were the over-determined products of political crisis. In the light of such over-determination it is probably pointless to ask whether Alfonso VIII really had a Jewish concubine, or whether it was "Queen Esther" and the ministerial powers she authorized who fell under the barons' bloody blades.

Regardless of the reality of our Jewess, real people, both Christians and Jews, felt the consequences of her death. Since it is relatively easy to see how Jews might be at risk from the circulation of an exemplary tale advocating so violent a prophylaxis to the dangers posed by Jewish power, we will focus on the Christian victims. Among the first of these may well have been King Sancho's own privado, Lope de Haro, murdered at court in Alfaro. Was the tale of Alfonso VIII's misguided love for his Jewess meant as an apologetic allegory of Sancho's own love for Lope de Haro? It seems plausible. Because the competition for power between the rival aristocratic lineages of Haro and Lara generated a great deal of the politics of late thirteenth-century Castile, chronicles produced in this period drew on the theme of conflict between the two houses in order to explain tensions between monarchical and aristocratic power. These explanations were sometimes set (like the Jewess) in the heroic past of Alfonso VIII's reign, the reign in which the house of Haro rose to prominence. ${ }^{42}$ But we need not insist on allegory. The general point is more important: it is no coincidence that the story of Alfonso VIII appeared and flourished when it did and not before. It throve in the loam of a half-century marked by struggle between 
aristocratic factions and a monarchy increasingly associated in the political imagination with the power of women, financial administrators, favorites, and Jews, powers here conflated in the figure of a Jewish concubine. The tale was very much a product of the period that told it.

It was also, however, productive of that period, providing as it did a powerful new literary form for political pursuits. ${ }^{43}$ It would be too much to say that the killing of "Esther" authorized the killing of privados, but certainly the Jewess' story gave flesh to a critique of the relationship between monarchs and ministers, a critique that proceeded by characterizing ministerial power in terms of deviant love and "Jewishness." In his "Rimado de Palacio," for example, Pero López de Ayala portrayed the Castilian court as a hotbed of intrigue for royal affection, in which the honeyed words of the Jews united king and favorite in a materialist love triangle. ${ }^{44}$ For López de Ayala, as for Gonzalo de Berceo in Theophilus' tale, it was a Jew who lurked near the court waiting to mislead love into a carnal and corrupt privanza.

Lust did not always require a "Jewish" face in order to do its critical work. Inés de Torres, confidante of the widowed queen and regent Catherine of Lancaster, "had such great privanza with the queen that all things were set free by her hand, so that affairs were not conducted as was required by the service of God, nor the good of her kingdoms." Inés' downfall came in 1416, when she was driven out of the court by accusations of sexual intercourse with a knight of the Royal Guard. Female sovereignty made the gender dynamics of the case extraordinary, but the logic is familiar: sexual access and political influence are mapped onto each other, with deviant love producing corrupt governance. ${ }^{45}$ Indeed the very exceptionality of the case makes clear the degree to which "amor" and "privanza" were eroticized in the politics of the day. A male privado posed grave sexual danger for a queen. A female favorite did not castrate the danger, but it did displace it, channeling the discourse of sexual access to the sovereign through the body of the privada.

Inés was not charged with "Judaism," perhaps because in the case of queens and their privadas politico-erotic transgression could be directly represented in terms of heterosexual adultery. Male monarchs and male ministers were more balefully bonded by the twin stars of Judaism and sexual seduction. We might almost say that, over time, privados became "Jewish concubines." The privanza of Alvaro de Luna under Catherine's son Juan II (r. 1405-1454) was loudly denounced as Judaizing (most markedly during the rebellion of 1449 with its attendant massacres of conversos), and the king's affection for him portrayed as unnatural. 
After decades of privanza Luna was executed at the king's command in 1453, but not before (according to the unfriendly chronicle of Alfonso de Palencia) he had taught sodomy to Juan Pacheco, who used it in turn to seduce Juan II's son Henry IV (r. 1454-74) and become his privado.

Unlike Luna, Pacheco survived the many plots of his rivals, and died a natural death. ${ }^{46}$ But even if the discursive dangers of Judaism and sodomy were not always lethal, they continued to stalk power and its agents. Late fifteenth-century poets (like the anonymous author of the "Coplas del Provincial") treated sodomite and Jew as standard terms of protest, aimed at magnates and high clergy alike. Late fifteenth-century chroniclers converted similar polemics into history. Writing triumphantly after the pacification of the kingdom under Isabel and Ferdinand, for example, Diego Rodríguez de Almela treated the theme of Jewish privanza not as a product of political conflict, but as a description of power and its exercise in the troubled centuries that had come before. ${ }^{47}$

Alfonso VIII's affair was pregnant with this politics of ministerial power and its critique: his Jewess was midwife to its birth. I am not claiming that her role was instrumental, or that it was often recognized during the long life-span of the politics she delivered. ${ }^{48} \mathrm{My}$ point is only that her figure redeployed a basic tension in Christian politics, the tension between "love of God" and "love of (wo)man," in such a way as to simultaneously enable and criticize new forms of governance. Writing his immensely influential "On the Government of Princes" at roughly the same time as King Sancho was composing his "Punishments," the Aristotelian theologian Giles of Rome put my assertion in slightly different terms: "in every ethical affair the way of proceeding, according to the Philosopher, is figural and gross." 49 Our beautiful Jewess was just such a negotiation, "figural and gross," of political (hence also, in pre-Machiavellian terms, moral) crisis and transformation.

It is important to insist, however, that neither love, nor Jews, nor lovely Jews, can be understood merely as products of this "figural" negotiation: they were also its arbiters. Though this claim is too large to be honored here, we can turn for down-payment to St. Augustine's hermeneutical handbook "On Christian Doctrine" (III.4-10), in which the Pauline confusion of "killing letter" with "quickening spirit," of literal meanings with figurative ones, is presented as the most basic danger of language. This error, which slays the soul and turns man into carnal beast, is (according to Augustine and many other Christian theologians) the error of the Jews. Augustine proposed a simple rule to help Christians avoid the danger and "find out whether a phrase is 
literal or figurative": whichever reading leads to love of God is to be preferred, whichever leads to lust for the world is false, for "scripture enjoins nothing but love, and condemns nothing but lust."

Augustine's notion of the "figural" is itself already the incarnation of a Christian hermeneutics of love and spirit which defines itself against a "Jewish" hermeneutics of lust and flesh.50 The friction caused by this intimate dependence could remain reasonably contained for readers (at least until Luther) of divine Scripture, axiomatically grounded as it was in divine love. For readers of worldly politics, the tension was greater from the beginning. Augustine himself put the problem starkly. Like Cain, who sinned by subjecting his reasoning soul to the desires of his flesh, every earthly city "has its good in this world, and rejoices in [the material world] with such joy as such things can afford," so that it will at the end of time be "committed to the extreme penalty." Just as (according to Augustine) secular power can never escape Cain's conjoined significations as both "founder of the earthly city" and "a figure of the Jews," ${ }^{51}$ neither can political love free itself entirely from lust for the material world. Political love was the foundation of sovereign power in the Christian republic, but it was a foundation built upon lust for Jewish flesh. It is within these foundations that Alfonso's Jewess was immured, and it is within them that the constitutional implications of her courtship become clear.

\section{Notes}

1. Guibert of Nogent's condemnation of John, Count of Soissons is in his De Vita Sua III.16. See the edition by ER Labande, Les Classiques de l'Histoire de France au Moyen Age, vol 34 (Paris, 1981), pp 422-429. For an English translation see JF Benton, Self and society in Medieval France. The memoirs of Abbot Guibert of Nogent (New York, 1970), pp. 209-11. The Jewess may have been a hypostasis of Guibert's more general claim here and elsewhere in his work that the Count was a Judaizer and heretic. On Guibert and the count more generally see J Rubinstein, Guibert of Nogent: portrait of a Medieval Mind (New York and London, 2002), pp. 116-124, and JM Ziolkowski, "Put in No-Man's Land: Guibert of Nogent's Accusations against a Judaizing and Jew-Supporting Christian," in Jews and Christians in twelfth-century Europe, ed. M Signer and J Van Engen (Notre Dame, 2001). On Pucellina see most recently S Einbinder (1998), Pucellina of Blois: romantic myths and narrative conventions, Jew H 12: 29-46. Einbinder understands the relationship (ahava) as one of protection rather than carnal love. The Estherka legend appears in Polish, Yiddish, and Hebrew sources, of which the earliest one known to me is D Ganz' sixteenth-century Zemab. David. On Estherka see H BarItzhak, Jewish Poland: Legends of Origin (Detroit, 2001), pp. 113-132; C Shmeruk, The Esterke story in Yiddish and Polish literature: a case study in the mutual 
relations of two cultural traditions (Jerusalem, 1985) [my thanks to Magda Teter for this last reference].

2. "Otrosi para mientes, mio fijo, e toma ende mio castigo de lo que contesçio al rey don Alfonso de Castilla, el que vençio la batalla de Hubeda, por siete annos que visco mala vida con vna judia de Toledo diole Dios grand llaga e grand majamiento en la batalla de Alarcos [1195], en que fue vençido e fuxo, e fue mal andante el e todos los de su regno. ... E demas matol los fijos varones e houo el regno el rey don Fernando, su nieto, fijo de su fija. E se repintio de tan mal pecado commo este que auia fecho, por el qual pecado, por emienda, fizo despues el monasterio de las Huelgas de Burgos de monjas de Cistel e el Espital, e Dios diole despues buena andança contra los moros en la batalla. E commo quier que y buena andança houo, muy mejor la ouiera si la desauentura de la batalla de Alarcos non le ouiera contesçido primero, en la qual desauentura el cayo por su pecado." Castigos e documentos para bien vivir, ed. A Rey (Bloomington, 1952), p 133. I have not used the new edition of HO Bizzarri (Madrid, 2001), nor compared the telling of the story across manuscript families. MJ Lacarra notes, however, no variation. See her "Los Exempla en los Castigos de Sancho IV: divergencias en la transmisión manuscrita" in La literatura en la época de Sancho IV, ed. C Alvar and JM Lucía Megías (Alcalá, 1996), pp 201-212. The work was completed in 1292-1293. On the debate over dating see the summary in F Gutiérrez Baños, Las empresas artísticas de Sancho IV el Bravo (Burgos, 1997), pp 205-206.

3. For surveys of the many early modern and modern works that expand upon the story see the pioneering essay by E Lambert (1923), Alphonse de Castille et la juive de Toléde, Bull Hisp 25: 371-397, and more recently, J Castañeda, A Critical Edition of Lope de Vega's Las paces de los reyes y judía de Toledo (Chapel Hill, 1962), pp 37-124.

4. Search for historical traces of this Jewess has been thorough but inconclusive. Because the Crónica Docampo named the Jewess "Fermosa" (almost certainly a misreading of the adjective "fermosa" in the Crónica de 1344 and in many manuscripts of the Crónica de Castilla), attention has focused on locating the name in Toledan records from the 1180s. In his argument against the truth of the story (see below), P Fita noted that the name was not to be found in among the 76 Hebrew epitaphs from Toledo published by Luzzato. Later generations of scholars have found a Fermosa, the wife of Tomé Saturnino, in Arabic documents. She is, however, almost certainly a Christian. See A González Palencia, Los mozárabes de Toledo en los siglos XII y XIII, vol 2 (Madrid, 1926), pp. 116 f., 127, 165 f., 175 f.; J Gómez Salazar (1951), Alphonse VIII de Castille et doña Fermosa, Evidences 22: 37-43, here p 42; J González, El reino de Castilla en la época de Alfonso VIII (Madrid, 1960), I, 26-38, here p 37; Pilar Leon Tello, Judíos de Toledo (Madrid, 1979), vol 1, pp. 40-42; G Hilty, "Die Jüdin von Toledo: Entstehung und Frühgeschichte des Motivs in der spanischen Literatur," in Verlust und Ursprung, Festschrift für Werner Weber, ed. A Maass and B Heinser (Zürich, 1989), pp. 241-267, here 261-263; and most recently idem, “ ¿Tiene raíces históricas el motivo de la judía de Toledo?" en Actas del IX Congreso de la Asociación Hispánica de Literatura Medieval, Noia, Toxosuoutos, 2005, pp 505-516, which Rafael Mérida brought to my attention too late for inclusion in this article.

5. Crónica de Castilla chap. 491, "conta o arçebispo dõ Rrodrigo." See the edition by $\mathrm{R}$ Lorenzo, La traducción gallega de la Crónica General y de la Crónica de Castilla (Orense, 1975), and on the dating, vol 1, pp XLIII-XLVI. F Docampo's Tercera 
Crónica General or Crónica Ocampiana (1541) relies heavily on the Crónica de Castilla for its account of the story but deletes the reference to Rodrigo, presumably out of familiarity with the Archbishop's work. On this point, and more generally on the redaction history of the tale, see above all Hilty, "Die Jüdin."

6. On the chronology and methodology of the Alfonsine historical project see Diego Catalán, De Alfonso X al Conde de Barcelos. Cuatro Estudios sobre el nacimiento de la historiografia romance en Castilla y Portugal (Madrid, 1962) (pp. 70-76, 88-93 specifically on the dating of the section on Alfonso VIII in the Primera Crónica); and his El taller historiográfico alfonsî. Métodos y problemas en el trabajo compilatorio, Romania 84 (1963):354-375. The story of Zaida is told in chapter 883 [ed. R Menéndez Pidal (Madrid, 1955), pp 552-554.] On Zaida see B Reilly, The Kingdom of León-Castilla under King Alfonso VI, 1065-1109 (Princeton, 1988), pp 234-235, 248, 328, 339-340.

7. My translation is from the Castilian version preserved in BNM Ms. 10815, fol. 145r, transcribed in Castañeda, p. 18, which is almost identical to the GallicianPortuguese Crónica de 1344. The latter, however, does not call the Jewess "muy fermosa," nor attribute her power to "fechiços y esperamiento quele ella sabia façer." Like the Crónica de Castilla, the Crónica de 1344 attributes the report to Rodrigo Jiménez de Rada, and describes the affair as lasting 7 months, not 7 years. On the dating of the various manuscripts (Portuguese and Castilian) of this last chronicle see D Catalán and M Soledad de Andrés, Crónica General de España de 1344 (Madrid, 1971), pp. XV ff.; and idem, De Alfonso X al Conde de Barcelos (Madrid, 1962), pp. 299-302.

8. The first summary of these debates, still invaluable, is that of G Cirot, "Alphonse le noble et la juive de Tolède," Bulletin hispanique 24 (1922): 289-306.

9. “...lo que hay de más inverosímil y de más afrentoso en el cuento, no es que el Rey se prendase de una judía muy hermosa, sino que los ricos hombres de Castilla se conjurasen para asesinar a una infeliz mujer." The quote is from Menéndez Pelayo, Estudios sobre el teatro de Lope de Vega IV, Obras Completas vol. 32 (Santander, 1949), p 89. Cf. Cirot, “Alphonse et la juive,” pp 293-294. Cirot (p. 305) argued for the reality of the affair, as does (most recently) Hilty, "Die Jüdin," p. 251, who believes that the author of the Castigos drew upon historical material assembled by the Alfonsine workshop, but doubts the murder.

10. Una judî muy fermosa: The Jewess as Sex Object in Medieval Spanish Literature and Lore, La Corónica 12 (1984): 187-94, here p 188. For a more recent reading of a (different) sexual discourse, that of sodomy, as "deeply conservative" see B Weissberger, “'iA tierra, puto!' Alfonso de Palencia's Discourse of Effeminacy,” in Queer Iberia: Sexualities, Cultures, and Crossings from the Middle Ages to the Renaissance, ed. J Blackmore and G Hutcheson (Durham, 1999), pp 291-324, here 294.

11. Proverbs 1:20-21, 5:1-23, 6:24-35, 7:1-27, 8:1-9:18, 23:27-28, 31:1-3 (addressed to King Lemuel of Massa by his mother: "Do not give your strength to women, your vigor to those who destroy kings"). On Proverbs as court and wisdom literature see the various essays in Studies in Israelite Poetry and Wisdom (Washington, D.C., 1971), as well as W Lee Humphreys, "The Motif of the Wise Courtier in the Book of Proverbs," in Israelite Wisdom: Theological and Literary Essays in Honor of Samuel Terrien (Missoula, 1978), ed. J Gammie et al., pp. 177-90. Proverbs forms part of an ancient genre of wisdom addressed from fathers to sons. The "Instructions of Onkhsheshonq," purporting to be written in prison by the 
Pharaoh's chief physician and councilor after his fall from favor, provide an Egyptian example. The relevance of this text for the study of biblical court legends such as those of the Book of Daniel has been noted by J Collins, The Apocalyptic Vision of the Book of Daniel (Missoula, 1977), p 33, and by J-C Lebram, Das Buch Daniel (Zurich, 1984), p 10. Its relevance for the Book of Esther (on which more below) was noted by LM Wills, The Jew in the Court of the Foreign King: Ancient Jewish Court Legends (Minneapolis, 1990), p. 43. On the dating of "Onkhsheshonq" see Miriam Lichtheim, Ancient Egyptian Literature, 3 vols (Berkeley, 1973-80), vol 3, p 159. Indeed so well worn was the genre of proverbs as paternal pedagogy that it was satirized already in Ancient Egypt, as when the son in the "Instructions of Any" responds to his father's wisdom with the words "It is worthless" (Lichtheim, Egyptian Literature, vol 2, p 135).

12. Excerpted from Proverbs 7:1-27.

13. The list differs from that given by Alfonso X, who counseled kings only against intercourse with relatives, and vile, religious, or married women, but made no mention of non-Christians (Siete Partidas 2.v.3). These injunctions for sexual restraint, royal or otherwise, were commonplace. For one among numerous contemporaneous examples see that of Sancho IV's own tutor, Juan G.I. de Zamora: De preconiis Hispaniae, ed. M Castro y Castro, O.F.M. (Madrid, 1955), pp 188-190 (which includes sodomy). Sancho's emphasis on the Jewess is, however, unusual.

14. Castigos, pp. 117-123. The proverb: "En juego nin en veras, con tu sennor non partas peras." Cf. Siete Partidas I.V.49.

15. Castigos, p. 127: "Otrosi non deues en afazimiento llegar el tu rostro a la cara de la judia, que es de aquella generaçion de los que escupieron a Jesu Cristo, tu sennor, en la faz."

16. For the importance of the theme in general, see M Halbertal and A Margalit, Idolatry (Cambridge, 1992), Chap. 1. On its importance in medieval Iberia, see Nirenberg, Conversion, sex, and segregation: Jews and Christians in Medieval Spain. The American Historical Review 107 (2002), pp 1065-1093.

17. Castigos, pp 31-32: "E en pena de aquesto ha querido Nuestro Sennor Dios que si el omne da sennoria a la muger sobre sy mesmo, que ela le sera todos tienpos contraria."

18. On the role of Rodrigo's sexual sin in late medieval ideologies of Castilian kingship see most recently B Weissberger, Isabel rules: constructing queenship. Wielding Power (Minneapolis, 2004), pp. 103-12. See also A Deyermond, The death and rebirth of Visigothic Spain in the Estoria de Espana, Revista canadiense de estudios hispánicos 9.3 (1985), pp. 345-67; and JR Burt, The motif of the fall of man in the 'Romancero del Rey Rodrigo, Hispania 61 (1978), pp 435-442. The idea that the Islamic conquest of the Visigothic monarchy was the product of a sexual turning away from God is, however, a much older one. In the year 746-747 Boniface explained to King Ethelbald of Mercia that the "peoples of Spain, Provence, and Burgundy" turned "away from God and lived in harlotry until the almighty judge let the penalties for such crimes fall upon them through... the coming of the Saracens." The Letters of St. Boniface, ed. And tr. E. Emerton (New York, 1976), p. 128.

19. On the much studied María de Molina see especially M Gaibrois de Ballesteros, María de Molina (Madrid, 1936), and most recently, M Jesús Fuentes, Reinas medievales en los reinos hispánicos (Madrid, 2003) pp 243-268. On the 
forged bulls, E Jaffe and H Finke, La dispensa de matrimonio falsificada para el rey Sancho IV y María de Molina, Anuario de Historia del Derecho Español 4 (1927), pp 298-318.

20. In addition to the text in the Primera Crónica cited above, see also Leyendas épicas Españolas, ed. R Castillo (Madrid, 1956), 151-155. Muslim writers also understood relationships between Christian lords and Muslim women in Iberia in terms of domination. See D Nirenberg, "Varieties of Mudejar Experience: Muslims in Christian Iberia, 1000-1526," in The Medieval World, ed. P Linehan and J Nelson (London, 2001), pp 60-76. Sancho himself translated the tombs of Alfonso VI and his wives Isabel and Zaida: See the Crónica de Sancho IV, in Crónicas de los reyes de Castilla, ed. C Rosell, Biblioteca de Autores Castellanos vol. 66 (Madrid, 1875), pp. $73-74$.

21. Llibre dels fets del rei en Jaume, ed. J Bruguera, vol 2 (Barcelona, 1991), p 13. See more broadly S Lipton, “Tanquam effeminatum': Pedro II of Aragon and the Gendering of Heresy in the Albigensian Crusade," in Queer Iberia, pp 107-129.

22. As Alfonso X put it sometime in the 1250s: "Si por ventura acaeciere que el rey tuviese otra mujer que no fuese de bendición... decimos que debe ser guardada por honra del rey." Leyes de Alfonso X, vol 1, Especulo, ed. G Martínez Díez (Avila, 1985), Libro II, título III, 1. A. Firpo ("Los Reyes Sexuales” parts I [Mélanges de la Casa de Velázquez 20 (1984), pp 217-227] and II [21 (1985), pp 145-58]) is one of many commentators who treats the extra-marital sexual activities of kings as "la representación misma de los valores de la virilidad." He suggests that sexual corruption became a revolutionary charge against kings as a consequence of increasingly powerful aristocratic attempts to decrease the prestige of monarchy (I, p 220), but that this did not occur until Enrique IV (II, p 147, though at I, p 226, he treats Pedro I as an earlier example).

23. Biblioteca Nacional, Madrid, ms. 10,815, fol. 145 v. Compare Ms. Escorial V.II.10 and 11, Diego Rodriguez de Almela, Compendio de las cronicas de España, cap. cccclxii $(81 \mathrm{v}-82 \mathrm{v})$ : De como el rey don alfonso de castilla caso con la reyna doña leonor fija del rey don enrrique de ynglaterra e de como estouo ençerrado en toledo con una judía e loque sobre aquello de la judía acaesçio. At fol. 82r: "a ti e al tu reyno por que telo consintio."

24. On the politics surrounding Alfonso's (and later Sancho's) use of Jewish administrators, and on the controversy over Isaac/Çag, the best narrative is still Y Baer, A history of the Jews in Christian Spain (Philadelphia, 1978), vol 1, 120-37. See also J-M Nieto Soria, "Los judíos de Toledo en sus relaciones financieras con la monarquía y la Iglesia (1252-1312)," Sefarad 41 (1981), pp 301-319, 42 (1982), pp 79-102. On the episcopal complaints, and on Sancho's role in investigating and amplifying them, see P Linehan, "The Spanish Church Revisited: the Episcopal gravamina of 1279," in Authority and Power: Studies on Medieval Law and Government Presented to Walter Ullmann on his Seventieth Birthday, ed. B Tierney and P Linehan (Cambridge, 1980), pp 127-147. The quote is from p 137. One of the bishops' complaints, transcribed on p 146, is that "los judios son puestos sobre los cristianos en los offiçios..., dela qual cosa vienen muchos males entre los quales e s mayor mal quelos cristianos son subiectos a ellos e son corrumpidos por sus costumbres e por sus malos husos." For examples of Sancho's anti-Jewish measures during the rebellion in 1282 see p 136, note 37 .

25. The most detailed study of Sancho's reign remains that of M. Gaibrois de Ballesteros, Historia del Reinado de Sancho IV de Castilla, 3 vols. (Madrid, 
1922-1928). On the Haro lineage see L. Salazar y Castro, Historia genealógica de la Casa de Haro (Madrid, 1966).

26. For a summary of these events see J.- M. Nieto Soria, Sancho IV, 1284-1295 (Palencia, 1994), pp. 83-98. The Cortes of 1288 are published in Cortes de los antiguos reinos de León y de Castilla, vol. 1 (Madrid, 1861), pp. 99-106. The Count's murder is described in the Crónica de Sancho IV, chap. 5, pp. 78-81. For the 15th century bishop Gonzalo de Hinojosa, author of the Continuación de la Crónica de España, the affair of Don Lope was so noteworthy that it fills the entire section devoted to Sancho's reign. Colección de Documentos ineditos para la historia de España, vol 106 (Madrid, 1893), pp 37-46.

27. See esp. MA Ladero Quesada, Fiscalidad y poder real en Castilla (1252-1369) (Madrid, 1993), and FJ. Hernández, Las rentas del rey. Sociedad y fisco en el reino castellano en el siglo XIII, 2 vols (Madrid, 1993). Some scholars have argued for the expanding role of Jews through the financial administrations of Alfonso XI and Pedro I. See, for example, M Kriegel, Les Juifs á la fin du Moyen Age dans l'europe mediterranéene (Paris, 1979), who presents these monarchs' use of Jews in administrative posts as an effort to build "'l'état de finance' moderne." (pp 59-69). It is commonplace to speak of Pedro I's "política filojudía," as does J Valdeón Baruque, Los judîos de Castilla y la revolución Trastámara (Valladolid, 1968), pp 25-38.

28. Castigos, p. 35. For my attempts to make this point convincing see "Christian Sovereignty and Jewish Flesh," forthcoming in The medieval senses, ed. S Nichols, J Küpper, et al.; "Warum der König die Juden beschützen musste, und warum er sie verfolgen musste," in Die Macht des Königs: Herrschaft in Europa vom Frühmittelalter bis in die Neuzeit, ed. B Jussen (Munich, 2005), pp 226-241; and "Figures of Thought and Figures of Flesh: 'Jews' and 'Judaism' in Late Medieval Spanish Poetry and Politics,” Speculum 81 (2006), pp 398-426.

29. On complaints about Peter's favor toward Jews see C Estow, Peter the cruel of castile: 1350-69 (Leiden, 1995), pp 154-179; and on his Jewish mother, M Kriegel, "Histoire sociale et ragots: sur l" "ascendance juive" de Ferdinand le Catholique," in Movimientos migratorios y expulsiones en la diáspora occidental (Pamplona, 2000), pp 95-100. The cases of Juan II and Enrique IV are discussed further below, but for the latter see generally L Suárez Fernandez, Enrique IV de Castilla: la difamación como arma politica (Barcelona, 2001). On Isabel as "protector of the Jews and daughter of a Jewess" see the account of the Polish traveler Nicolas Popplau, in J Liske, Viajes de extranjeros por España y Portugal en los siglos XV, XVI, y XVII : colección (Madrid, 1878).

30. Both advised repudiating María in favor of a legitimate marriage. The Crónica de Sancho IV understood well the fragility of her situation throughout these negotiations: "commo era mujer de grande entendimiento, é que veia commo el rey andava en poder del Conde é de aquellos sus privados... é que era amenguamiento del Rey é daño della é de sus hijos, non ovo á quien tornar, salvo á Dios...” (p 75). On Abbot Gómez see P Lorenzo Gradín “Gómez García, Abade de Valadolide," in La literatura en la epoca de Sancho IV, pp 213-226.

31. Surprisingly little has been written on royal concubinage in Castile. See, for example, A Firpo, "Las concubinas reales en la Baja Edad Media castellana," in $L a$ condición de la mujer en la Edad Media (Madrid, 1986), pp 334-341. On queenship see most recently M Jesús Fuente, Reinas medievales. For the later period B Weissberger's Isabel rules is very useful. 
32. Estow, Pedro the cruel, Chapter 6, here p 149. One of the chief complaints of the magnates was that Pedro preferred his concubine's family to candidates from the nobility. The practice of favoring blood relations for office was an ancient practice, recommended as well by the Siete Partidas II.viii.1.

33. Romancero del rey Don Pedro, 1368-1800, ed. A. Pérez de Gómez (Valencia, 1954), Romance IX, p. 134. Recall that some versions of the Jewess' story also attributed her power over Alfonso VIII to "fechiços y esperamientos quele ella sabia façer." On the Romancero tradition about Pedro see L. Mirrer-Singer, The Language of Evaluation: a Sociolinguistic Approach to the Story of Pedro el Cruel in Ballad and Chronicle (Amsterdam, 1986); Anne J. Cruz, "The Female Figure as Political Propaganda in the 'Pedro el Cruel' Romancero," in Spanish Women in the Golden Age, Images and Realities, ed. Magdalena S. Sánchez and Alain Saint-Saëns (Westport, CT, 1996), pp. 69-89.

34. Cf. Siete Partidas II.viii.1. Similarly Don Juan Manuel advises in the early 14th century that lords fill the important office of chancellor with a "privado," selected from "sus criados." Libro de los Estados chap. 95.

35. Gonzalo de Berceo, Milagros de Nuestra Seńora, ed. AG Solalinde (Madrid, 1978), Milagro 25, 791b.

36. In the context of clerical private life, however, the word was easily sexualized. Alfonso X, for example, used it to designate the danger zone confronting clerics whose domestic needs were tended to by female relatives. Siete Partidas I.vi.38: "pero con todo esto guardarse deben ellos que non hayan con ellas grant privanza nin grant afazimiento, ca por engaño ó por descibimiento del diablo algunos clérigos cayeron...."

37. The Jewess' resemblance to the Biblical Esther, and also to the Estherka of Poland's King Casimir (see note 1, above), was noted early by Lambert, "Alphonse de Castille," pp 371-372, citing Longinus' Historia Polonica.

38. See, for example, the coronation formulas edited by R Elze in Ordines coronationis imperialis. Die Ordines für die Weihe und Krönung des Kaisers und der Kaiserin (MGH Fontes iuris Germanici antiqui in usum scholarum vol 9) (Hannover 1960). The first (p. 8) is ca. 900 c.e.: "ineffabilem misericordiam tuam supplices exoramus, ut sicut Esther reginam Israelis causa salutis de captivitatis suae compede solutam ad regis Assueri thalamum regnique sui consortium transire fecisti, ita hanc famulam tuam N. ..." My thanks to Claudius Sieber-Lehmann for the reference.

39. For an excellent beginning focused on Jewish exegesis see BD Walfish, Esther in Medieval Garb: Jewish interpretations of the book of Esther in the Middle Ages (Albany, 1993).

40. Medieval Jewish commentaries on Esther seem aware of the potential for negative Christian readings of the Book. Some defend Ahasueros as a good king, while others put Christian anti-Jewish arguments in the mouth of Haman (as when Abraham Shalom has Haman warn Ahasueros that if the king tolerates the Jews in his lands he will be suspected of heresy by some of his subjects [la-hashov 'al ha-melekh toah"]. Rabbi Shemeriah b. Elijah of Crete even stressed that Esther had kept her Judaism a secret from the king, for "if it became known that she was Jewish, everyone would think that she was behind the king's actions and that the king acted unjustly out of love for his wife. It would make matters very difficult for the king's officers to say that the king chose as his queen a Jewish woman, a member of a people who hated all other peoples, and out of love for her ordered that his best officers... be hanged..." These examples are from Walfish, pp 148-149, 164. 
41. Later authors tended to bring the story's details into ever-greater conformity with the Esther narrative. In his Raquel, tragedia española en tres jornadas (1783), for example, Vicente García de la Huerta added a "Reuben" to parallel Esther's Mordechai, and inserted the theme of an anti-Jewish decree that the concubine seeks to overturn and avenge. JG Fucilla's edition of Raquel (Madrid, 1974) is, it should be noted, preceded by a helpful survey of the history of Alfonso's Jewess in Castilian drama.

42. According to one chronicle tradition, for example, Don Diego López de Haro advised Alfonso VIII to impose the pecha tax on the hidalgos of his realm. The hidalgos rebeled under the leadership of the house of Lara, and Don Diego was exiled. See G Cirot (1926), Anecdotes ou légendes sur l'époque d'Alphonse VIII, Bull Hisp 28: 246-59; and J Paredes Núñez, "Sancho IV y su tiempo en la literatura genealógica peninsular," 235-243. It has already been noted by González , p. 40 ff., and Hilty, pp 251-255, that the story of the Jewess bears some traces of this conflict between lineages. The Crónica de Castilla explicitly names Don Diego as leader of the tepid faction at Alarcos, while the Primera Crónica General (Ch. 1006; Menéndez Pidal 1955, p 685) attributes to the advice of this same Don Diego the expiatory foundation of Las Huelgas. On the rise of the lineage in the reign of Alfonso VIII see González, Alfonso VIII, pp 300-307.

43. Cf. L Montrose: "to speak of the social production of 'literature' or of any particular text is to signify not only that it is socially produced but also that it is socially productive - that it is the product of work and that it performs work in the process of being written, enacted, or read." "Professing the Renaissance: The Poetics and Politics of Culture," in The New Historicism, ed. H Aram Vesser (New York, 1989), p. 20.

44. "Libro de Poemas" o "Rimado de Palacio", ed. M García, 2 vols (Madrid, 1978), especially strophes $234-297,422-534$. On the difficulty of choosing the right privado to love, see strophe 289 .

45. The quote is from the Crónica de Don Juan II by Lorenzo Galindez de Caravajal, in Crónicas de los Reyes de Castilla, vol 2, ed. Cayetano Rosell, Biblioteca de Autores Españoles vol. 68 (Madrid, 1877), year 1416, ch. x, p 372. The poems addressed by Ferrant Manuel de Lando to both exiles are preserved in the Cancionero de Baena, ed. B Dutton and J González Cuenca (Madrid, 1993), \#277 and 278 (pp 477-479). \#277 (to Inés) is a meditation on Fortune and privanza. A humanistic funeral oration for Inés by Giannozzo Manetti has been edited by J Lawrance, Un episodio del proto-humanismo Español: tres opúsculos de Nuño de Guzmán y Giannozzo Manetti (Salamanca, 1989), pp 129-192. The exile is mentioned at page 170.

46. On the extent to which Luna's administrative reforms laid the groundwork for the "state" of the Catholic Monarchs, see Nicholas Round, The Greatest Man Uncrowned: a Study of the Fall of Don Alvaro de Luna (London, 1986), p 21. On Luna as favorer of Jews and conversos see inter alia B Netanyahu, The Origins of the Inquisition in Fifteenth Century Spain (New York, 1995), pp 236 ff. For discussions about the erotics of Luna's relationship with Juan II see G Hutcheson, "Desperately Seeking Sodom: Queerness in the Chronicles of Alvaro de Luna," in Queer Iberia, pp 222-249. Alfonso de Palencia's claim about Luna's pedagogy of Juan Pacheco is in his Gesta Hispaniensia, ed. B Tate and J Lawrence (Madrid, 1998), I.1, pp 3-4. On sexual representations of Enrique IV see Barbara Weissberger, "A tierra puto." Though more interested in Palencia's discourse of effeminacy than Judaism, Weissberger remarks helpfully on the intersection of the 
two in the compound insult "faggot Jew" (puto judio), at p 294. On Pacheco's survival of the many plots of his enemies against him, see Fernando del Pulgar, Claros Varones de Castilla, ed. Robert Brian Tate (Oxford, 1971), pp. 29-33: "And though they sometimes came near to having him executed, he was freed by unexpected and admirable twists of fortune from the chains of death that they had placed upon him."

47. For the Coplas see M Ciceri, "Las Coplas del Provincial," Cultura Neolatina 35 (1975), pp 39-210. See also J Rodríguez-Puértolas, ed., Poesîa de protesta en la Edad Media castellana (Madrid, 1968). Diego Rodríguez de Almela spoke of "la gran priuanca que en aquel tiempo tenian los judios con los Reyes \& grandes señores asi ecclesiasticos commo seglares destos regnos despaña." Valerio de las historias eclesiásticas y de España (Murcia, 1487), fol. 20v.

48. Though clearly the sixteenth and seventeenth century dramatists who staged and re-staged her story did so in order to make critical sense of contemporary politics. See for example D Luis de Ulloa y Pereyra adaptation of the theme in a poetic reproach addressed to the king in 1650, after the disgrace of the privado CountDuke of Olivares: "Alfonso Octavo Rey de Castilla, Príncipe perfecto, detenido en Toledo por los amores de Hermosa o Raquel, Hebrea, muerta por el furor de los Vasallos," in his Versos (Madrid, 1659). Jacques Basnage, who first encountered the story of Alfonso VIII in Mariana's Histoire générale d'Espagne, underlined its political implications in his Histoire des Juifs as neither Mariana nor any other Spanish historian previous had done; see Jacques Basnage, Histoire des juifs, nouvelle edition augmentée (The Hague: Henri Scheurleer, 1716), vol 13, book 9, ch.xii.4-5, pp 318-321. The importance of the theme needs to be understood in the wider context of the staging of kings and privados in early modern politics and drama, for which there is an extensive bibliography. For a beginning, The world of the favorite, ed. JH Elliott and WB Brockliss (New Haven, 1999). See also A. Feros, "Almas gemelas: monarcas y favoritos en la primera mitad del siglo XVII," in España, Europa y el mundo Atlántico, ed. R Kagan and G Parker (Madrid, 2001 [English original Cambridge, 1995]), pp. 49-81; and idem, “'Vicedioses, pero humanos,' el drama del Rey," Cuadernos de Historia Moderna 14 (1993), pp 103-131.

49. "in toto morali negotio modus procedendi, secundum Philosophum, est figuralis et grossus." Aegidius Romanus [Giles of Rome], De regimine principum libri III, I.i.1 (Rome 1607/1967), p 2. Giles is referring here to Aristotle's Nichomachean Ethics, Book 2, 1104a. "Figuralis" is his translation of Aristotle's tupô: a difference that seems to me of vast significance for medieval political theology. On the De regimine, see (among many other titles) Ch. F. Briggs, Giles of Rome's De regimine principum. Reading and Writing Politics at Court and University, c. 1275-c.1525 (Cambridge, 1999).

50. This seems to me one of the many insights toward which E. Auerbach was gesturing in his "Figura" [Neue Dantestudien 5 (Istanbul, 1944), pp 11-71], though it is one he chose not to make explicit.

51. De civ. dei, 15.4-5, 7. Cain's politics give priority to flesh, "that part which the philosophers call vicious, and which ought not to lead the mind, but which the mind ought to rule and restrain by reason." Augustine's prooftexts here come significantly from Galatians (5.17) and Romans $(7.17,6.13)$. 